\title{
A Látrányi Puszta Természetvédelmi Terület futóbogár faunájának vizsgálata (Coleoptera: Carabidae)
}

\author{
ROZNER GYÖRGY
}

\author{
Duna-Dráva Nemzeti Park, H-8693 Kisberény, Petőfi u.1., Hungary
}

ROZNER Gy: Investigation on carabid fauna of the Látrányi Puszta Nature Conservation Area (Coleoptera: Carabidae)

Abstract: In the present paper the results of a four-year-long research is published on the Látrányi Puszta Nature Conservation Area. As a result of the survey, 120 species were recorded which equals to the $46 \%$ of the carabid fauna of Somogy County, and represents $25 \%$ of the Hungarian fauna.

Key words: Carabidae, faunistical survey, nature conservation, South Hungary

\section{Bevezetés}

A Látrányi Puszta Természetvédelmi Terület Somogy megye egyik legértékesebb része. Külső-Somogy lösz dombjai közé ékelődött homokterületet az egykori Balaton homok dủnéi alkotják és bizonyos mértékben kapcsolatban áll az egykori Nagyberek területével is. További érdekessége, hogy eltérő származása miatt semmilyen kapcsolatban sincs a Belső Somogyi savanyú homokterületekkel, inkább meszes homok az alapkőzet. Ezek a feltételek összességében egy nagyon fajgazdag terület kialakulását tették lehetővé, melyen rendkívül mozaikosan megtalálhatjuk a nyílt homoki gyepeket, a különböző típusú lápréteket és különféle erdőtársulásokat is. A területet 1992-ben nyilvánították védetté.

A Látrányi Puszta Természetvédelmi Terület rendszeres zoológiai felmérése 1999. tavaszán kezdődött igen szük keretek között, illetve néhány korábbi adattal is rendelkeztünk a területről. Az eltelt négy év során a program kiteljesedett és sorozatban hozta a meglepő eredményeket, melyek igazolták előzetes várakozásainkat.

\section{Anyag és módszer}

A mintavételi helyeket igyekeztem úgy megválasztani, hogy jól reprezentálják a terület rendkívül változatos élőhelyeit. Ennek ellenére úgy látom, hogy van tere a további kutatásoknak is, mert a különböző területrészeken az azonos típusú élőhelyeken eltérő fajösszetételt tapasztaltam.

A futóbogár fauna vizsgálatát elsősorban talajcsapdás gyűjtésekre alapoztuk, amit számos egyéb módszerrel egészítettünk ki.

A talajcsapdás gyüjtésekhez három decis műanyag poharakat használtam, melybe ecetes vizet tettem csalétek gyanánt. A csapdákat a különböző élőhelyeken vonalban helyeztem el és rendszeresen ürítettem azokat.

A négy év során az alábbi helyeken üzemeltettem a csapdákat:

1. A Kolláti-legelő K-i oldalán elterülő füzes erdőfolt.

2. A Kolláti-legelő K-i oldalán található homokdombon, nyílt homoki gyepen. 


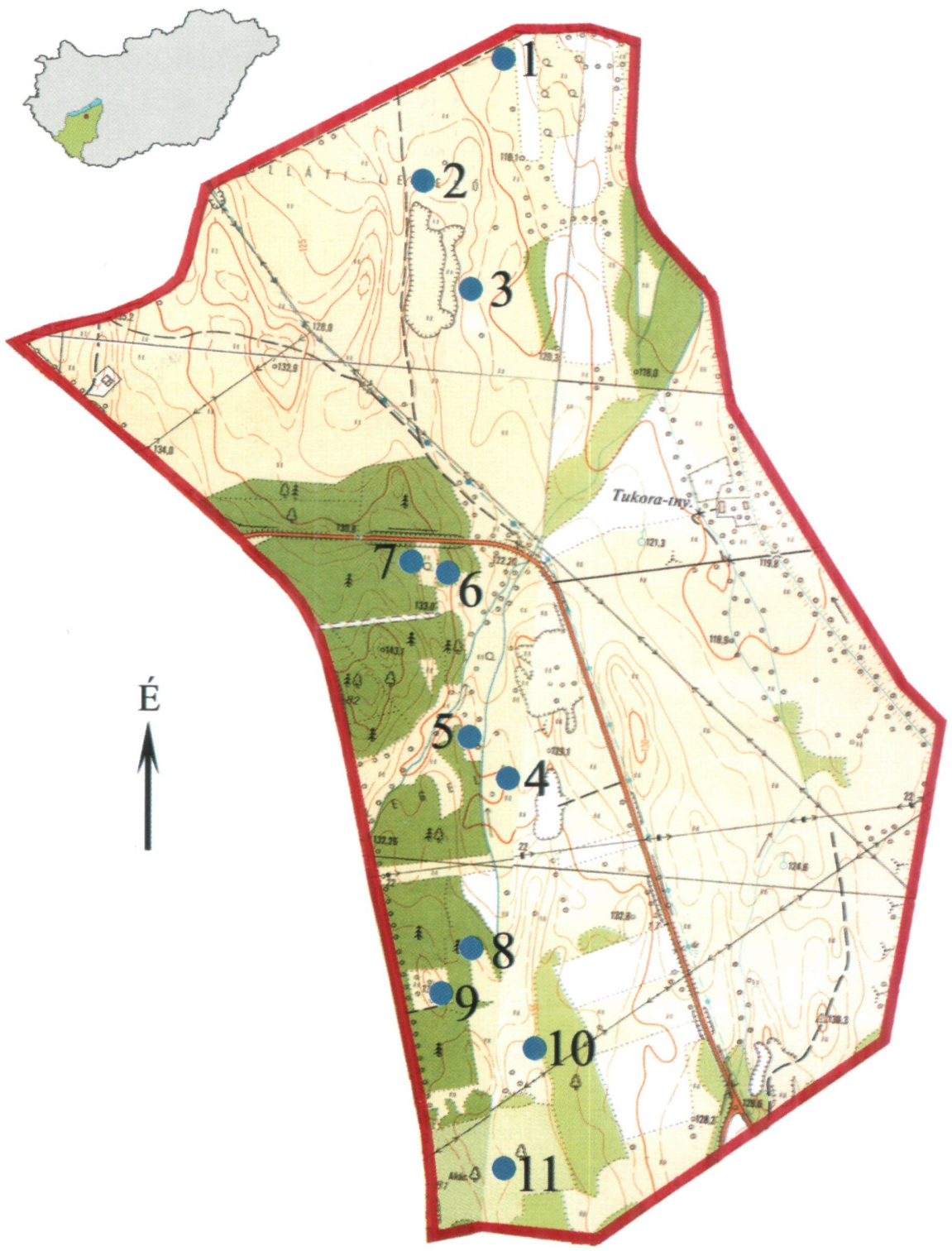


3. A Kolláti-legelő K-i oldalán fekvő felhagyott bányagödör és a mellette lévő láprét

4. Birkás-legelö- a viszi úttól Ny-ra fekvő nagy homok domb.

5. Birkás-legelö- a viszi úttól Ny-ra fekvő égeres erdő.

6. Birkás-legelö- a viszi úttól Ny-ra fekvő árok melletti galéria erdő.

7. Birkás-legelö- a viszi úttól Ny-ra fekvő magassásos.

8. Birkás-legelö- a viszi úttól Ny-ra fekvő cseres.

9. Birkás-legelö- a viszi úttól Ny-ra fekvő fenyves és akácos.

10. Birkás-legelő- a viszi úttól Ny-ra fekvő beerdősülő homokpuszta, fás-bokros terület.

Sok adat származik Szinetár Csaba talajcsapdás gyüjtéseiböl is, aki hasonló típusú élőhelyeken, de részben eltérő területrészeken folytatta a gyüjtéseket.

Jelentös mennyiségü adat származik egyéb kiegészítő gyűjtési módszerek alkalmazásából. Ezek egyelés, fühálózás és lámpás illetve fénycsapdás gyüjtésekből, valamint autós hálózásból származnak.

\section{Eredmények}

A listán szereplő minden példány a Látrányi puszta TT területéről, egyben Látrány községhatárból származik, így a község nevét külön nem tüntettem föl. A faj neve után a közelebbi lelöhely megnevezése következik, majd a gyüjtés dátuma, majd zárójelben a gyüjtési módszer, a fogott darabszám és más gyüjtő esetében annak neve szerepel.

A listában használt röviditések:

$$
\begin{aligned}
& \text { tcs- talajcsapda } \\
& \text { fh- füháló } \\
& \text { egy- egyelés } \\
& \text { fcs- fénycsapda } \\
& \text { ah- autós hálózás }
\end{aligned}
$$

\section{Carabidae}

Leistus rufomarginatus Duftschmid, 1812.

Birkás-legelö, 2001. 05. 07 - 06. 14. (tcs., 4):

2002. 06. 16. (tcs., Sz.Cs., 2)

Leistus ferrugineus Linnaeus, 1758.

Kolláti-legelö, 1999. 04. 15 - 05. 22. (tcs., 1)

Leistus piceus piceus Fröelich, 1799.

Birkás-legelő, 2001. 05. 07 - 06. 14. (tcs., 1):

Birkás-legelö, 2001. 06. 14 - 07. 19. (tcs., 3): 2002.

06. 16. (tcs., Sz.Cs.,1)

Nebria brevicollis Fabricius, 1792.

Birkás-legelö, 2001. 05. 07 - 06. 14. (tcs., 3): Birkás-legelö, 2001. 06. 14 - 07.19. (tcs., 2): égeres, 2001. 06. 17 - 07. 09. (tcs., Sz.Cs., 1): Birkás-legelö, cseres, 2002. 06.13 - 07. 15 (tcs., 2)

Notiophilus rufipes Curtis, 1829

Birkás-legelö, 1999. 05. 22 - 06. 24. (tcs., 2)

Notiophilus palustris (Duftschmid, 1812)

2002. 06. 16. (tcs., Sz.Cs., 7)

Carabus granulatus Linnaeus, 1758

Birkás-legelö, 1999. 05.22 - 06. 24. (tcs., 1): Birkás-legelö, 2001. 04. 18 - 04. 25. (tcs.,2): Birkáslegelö, 2001. 05. 07 - 06. 14. (tcs., 24): Birkás-legelő, 2001. 06. 14 - 07. 19.(tcs.,9): láprét L1, 2001. 06. 17 - 07. 09. (tcs., Sz.Cs., 1)

\author{
ÁL- Ábrahám Levente \\ SzCs- Szinetár Csaba \\ RI- Rozner István \\ PA- Podlussány Attila \\ MO- Merkl Ottó
}

Carabus ullrichi Germar, 1824

Birkás-legelö, 2001. 06. 14 - 07. 19. (tcs., 4): égeres, 2001. 06. 17 - 07. 09. (tcs., Sz.Cs., 20)

Carabus cancellatus Illiger, 1798

1998. 04. 24 - 05. 15. (tcs., 2): 1998. 05.16 - 06. 22. (tcs., 7): Kolláti-legelö, 1999. 03. 05 - 03. 31. (tcs., 1): 1999. 04. 01 - 04. 14.(tcs., 4): 1999. 04. 15 . 05. 22. (tcs., 5): Birkás-legelö, 1999. 04. 25 - 05. 22. (tcs., 2): 1999. 05. 22 - 06. 24. (tcs., 3): Birkás-legelö, 2001. 04. 10-04. 18. (tcs., 1): Birkás-legelö, 2001. 04. 18 - 04. 25. (tcs., 10): Birkás-legelő, 2001. 05.07 - 06. 14. (tcs., 211): Birkás-legelö, 2001. 06. 14 - 07. 19. (tcs., 38): égeres, 2001. 06. 17 - 07. 09. (tcs., Sz.Cs., 65): láprét L3, 2001. 06. 17 - 07. 09. (tcs., Sz.Cs., 51): láprét L1, 2001. 06. 17 - 07. 09.(tcs., Sz.Cs., 33): Birkás-legelö, cseres, 2002. 06. 13 - 07. 15 (tcs.,1): Birkás-legelő, akácos, 2002. $06.13-07$. 15 (tcs., 1)

Carabus hortensis Linnacus, 1758

Birkás-legelö, égeres, 1999. 04. 01 - 04. 14. (tcs., 1): 1999. 05. 22 - 06. 24. (tcs., 1): Birkás-legelö, 2001. 04. 18 - 04. 25. (tcs., 1): Birkás-legelö, 2001. 05.07 - 06. 14. (tcs., 29): Birkás-legelö, 2001. 06. 14 - 07. 19. (tcs.,77): Birkás-legelő, cseres, 2002. 06.13 -07.15 (tcs., 1) 
Carabus convexus Fabricius, 1775

1998. 04. 24 - 05. 15. (tcs., 1): Kolláti-legelö, 1999. 04. 01 - 04. 14. (tcs., 1): Birkás-legelő, 1999. 04.01-04. 14. (tcs., 2): 1999. 05. 24 - 06. 24. (tcs., 3): Birkás-legelö, 2001. 05. 07 - 06. 14. (tcs.,6): Birkáslegelö, 2001. 06. 14 - 07. 19. (tcs., 2): égeres, 2001. 06.17 - 07. 09. (tcs., Sz.Cs., 2): Birkás-legelő, aká$\cos , 2002.06 .13-07.15$ (tcs.,3)

Carabus germari exasperatus Duftschmid, 1812

- Birkás-legelö, 2001. 05. 07 - 06.14.(tcs., 1): égeres, 2001. 06. 17 - 07. 09. (tcs., Sz.Cs., 3): láprét L3, 2001 .06. 17 - 07. 09. (tcs., Sz.Cs., 2): Birkás-legclö, akácos, 2002. 06. 13 - 07. 15 (tcs.,1)

Carabus coriaceus Linnaeus, 1758

1998. 04. 24 - 05. 15. (tcs., 1): Birkás-legelö, 2001. 04. 18 - 04. 25. (tcs., 1): Birkás-legelő, 2001. 05.07 - 06. 14. (tcs., 1): Birkás-legelö, 2001. 06. 14 07. 19. (tcs., 1)

Cychrus caraboides caraboides Linnaeus, 1758

Birkás-legelö, 2001.05. 07 - 06. 14. (tcs., 1)

Cicindela soluta pannonica Mandl, 1935

Legelö, 1998 04. 24. (egy.,1): Kolláti-legelö, 1999. 04. 14. (egy., 6): Kolláti-legelö, 1999. 05. 22 06. 24. (tcs., 1): 1999. 04. 30. (egy., 3, Á.L.): 2001. 04. 24. (egy., 1)

Omophron limbatum Fabricius, 1776

Kolláti-legelö, 2000. 04. 11. (egy., 1)

Elaphrus cupreus Duftschmid, 1812

Birkás-legeló, ćgeres patakpart, 2002. 05. 02. (egy., 1)

Elaphrus uliginosus Fabricius, 1792

2002. 06. 16 (tcs., Sz.Cs.,5)

Elaphrus riparius (Linnaeus, 1758)

2002. 06. 16. (tcs., Sz.Cs., 1)

Clivina collaris (Herbst, 1784)

Birkás-legelő, 2002. 05. 04. (ah.,M.O.,1)

Clivina fossor (Linnacus, 1758)

láprét L3, 2001. 06. 17 - 07. 09. (tcs., Sz.Cs., 1): 2002. 06. 16. (tcs., Sz.Cs.,5): Kolláti-legelö, 2002. 06. 19. (fes.,2)

Dyschirius aeneus (Dcjean, 1825)

2002. 06. 19. (fcs., 1)

Dyschirius globosus (Herbst, 1783)

2002. 06. 16. (tcs., Sz.Cs.,6)

Asaphidion flavipes (Linnaeus, 1761)

Birkás-legelö, akácos, 2002. 06. 13 -07. 15 (tcs., 1)

Bembidion laticolle (Duftschmid, 1812)

2001 08. 16. (cgy., 1)

Bembidion properans (Stephens, 1828)

legelő, 1998. 04. 24. (egy., 1): 2002. 06. 16. (tcs.,

Sz.Cs., 1)

Bembidion punctulatum Drapiez, 1820

2001. 05. 16. (fcs., Á.L., 1)

Bembidion assimile Gyllenhal, 1810

2002. 06.1 6. (tcs., Sz.Cs., 1)

Bembidion dentellum Thunberg, 1787

2001. 07. 11. (fcs., Á.L., 1): 2002. 06. 16. (tcs., Sz.Cs.,7)

Bembidion varium Olivier, 1795

Kolláti-legclő, 2001. 06. 16.(fcs., 1): 2001. 07.
31. (fcs., Á.L., 2): Kolláti-legelö, 2002. 06. 19. (fcs., 2) Bembidion dalmatinum Dejean, 1831

1999. 06. 07. (Á.L., 4): 2001. 07. 11. (fcs., Á.L.,

1). Birkás-legelő, 2002. 05. 04. (ah.,M.O.,2): 2002.

06. 16. (tcs., Sz.Cs., 1)

Bembidion inoptatum Schaum, 1857

Birkás-legelö, 2002. 05. 04. (ah.,M.O.,1):

Bembidion lunulatum (Fourcroy, 1785)

Birkás-legelö, 2001. 04. 25. (cgy., 1)

Bembidion mannerheimi C.R.Sahlberg, 1827

2002. 06. 16. (tcs., Sz.Cs., 1)

Bembidion quadrimaculatum (Linnaeus 1761)

Birkás-legelő, 2002. 05. 04. (ah.,M.O.,1):

Bembidion quadripustullatum (Serville, 1812)

2001. 07. 11. (fcs., Á.L., 1)

Bembidion guttula (Fabricius, 1792)

2002. 06. 16. (tcs., Sz.Cs.,4)

Bembidion biguttatum (Fabricius, 1779)

Birkás-legelō, 2002. 04. 26. (egy., 1):

Trechus quadristriatus Schrank, 1781

Kolláti-legelő, 2001. 06. 16.(fcs., 1): 2002. 06.

16. (tcs., Sz.Cs.,5)

Paratachys bistriatus (Duftschmid, 1812)

Birkás-legelö, 2002. 05. 04. (ah.,M.O.,2): 2002.

06. 19. (egy., 1)

Porotachis bisulcatus (Nicolai, 1822)

Birkás-legelö, 2002. 05. 04. (ah.,M.O.,1):

Stomis pumicatus (Panzer, 1796)

Birkás-legelö, 2001. 04. 18 - 04. 25. (tcs., 1): ćgercs, 2001. 06.17 - 07. 09. (tcs., Sz.Cs., 1): 2002. 06. 16. (tcs., Sz.Cs.,1)

Poecilus cupreus Linnaeus, 1758

Kolláti-legelö, 1999. 04. 01 - 04. 14. (tcs., 2): Birkás-legelö, 2000. 04. 11. (cgy., 3): Birkás-legelö, 2002. 06. 13 - 07. 15 (tcs., 1)

Poecilus versicolor Sturm, 1824

láprét L3, 2001. 06. 17 - 07. 09. (tcs., Sz.Cs., 3): 2002. 06. 16. (tcs., Sz.Cs.,33): Birkás-legelő, akácos, 2002. 06. 13 - 07. 15(tcs.,2)

Pterostichus vernalis Panzer, 1796

Birkás-legelō, 2001. 05. 07 - 06. 14. (tcs., 6): Birkás-legelö, 2001. 06. 14 - 07. 19. (tcs., 7): 2002. 06. 16. (tcs., Sz.Cs.,21)

Pterostichus strenuus Panzer, 1797

Birkás-legelö, 1999. 03. 05 - 03. 31. (tcs., 1): Birkás-legelö, 2001. 04. 18 - 04. 25. (tcs., 2): Birkáslegelö, 2001. 05. 07 - 06. 14. (tcs., 11): Birkás-legelö, 2001. 06. 14 - 07. 19. (tcs., 2): ćgeres, 2001. 06. 17 07. 09. (tcs., Sz.Cs., 1): láprét L1, 2001. 06. 17 - 07. 09. (tcs., Sz.Cs., 3): Birkás-legelö, 2001. 10. 05. (egy., 1): 2002. 06. 16. (tcs., Sz.Cs.,1)

Pterostichus anthracinus Illiger, 1798

2001. 04. 12. (egy., 1): 2002. 06. 16. (tcs., Sz.Cs.,36)

Pterostichus gracilis Dejean, 1828

Kolláti-legelő, 2001. 06. 16. (fcs., 1)

Pterostichus nigrita Paykul, 1790

Birkás-legelö, 2001. 04. 10 - 04. 18. (tcs., 1): Birkás-legelô, 2001. 04. 18 - 04. 25. (tcs.,2): Birkáslegelö, 2001. 05. 07 - 06. 14. (tcs., 10): Birkás-lege- 
lö, 2001. 06. 14 - 07. 19. (tcs., 2): 2002. 06. 16. (tcs., Sz.Cs.,10)

Pterostichus oblongopunctatus Fabricius, 1787

1998. 04. 24 - 05. 15. (tcs., 6): Birkás-legelö, 1999. 03.05 - 03. 31. (tcs., 1): 1999.04. 01 - 04. 14. (tcs., 2): 1999. 05. 22 - 06. 24. (tcs., 2): Birkás-legelö, 2001. 04. 10 - 04. 18. (tcs., 2): Birkás-legelő, 2001. 04. 18 - 04. 25. (tcs., 10): Birkás-legelő, 2001. 05.07 - 06. 14. (tcs., 25): Birkás-legelö, 2001. 06. 14 - 07. 19. (tcs., 2): 2002. 06. 16. (tcs., Sz.Cs.,5)

Pterostichus melanarius Illiger, 1798

Birkás-legelö, 1999. 04. 25 - 05. 22. (tcs.,5): 1999. 05. 22 - 06. 24. (tcs.,1): Birkás-legelö, 2001. 05. 07 - 06. 14. (tcs., 9): Birkás-lcgelő, 2001. 06. 14 . 07. 19. (tcs., 13): égeres, 2001. 06. 17 - 07. 09. (tcs., Sz.Cs., 13): láprét L3, 2001. 06. 17 - 07. 09. (tcs., Sz.Cs., 1): 2002. 06. 16. (tcs., Sz.Cs.,22)

Pterostichus niger Schaller, 1783

Kolláti-legelö, 1999. 04. 01 - 04. 14. (tcs., 1): Birkás-legelö, 2001. 05. 07 - 06. 14. (tcs., 4): Birkáslegelö, 2001. 06. 14 - 07. 19. (tcs., 31): égeres, 2001. 06. 17 - 07. 09. (tcs., Sz.Cs., 2): láprét L3, 2001. 06. 17 - 07. 09. (tcs., Sz.Cs., 2): Kolláti-legelő (1.sz.tcrület), 2001. 07. 05. (fh.,M.O.,1): 2001. 07. 11.( fcs., Á.L., 1): 2002, 06. 16. (tcs., Sz.Cs.,11)

Abax paralellepipedus Piller et Mitterpacher, 1783 Birkás-legelö, 2001. 04. 10 - 04. 18. (tcs., 1): Birkás-legelő, 2001. 05. 07 - 06. 14. (tcs., 2): Birkáslegelö, 2001. 06. 14 - 07. 19. (tcs., 1)

Abax carinatus Duftschmid, 1812

Birkás-legelö, 2001. 05. 07 - 06. 14. (tcs., 2):

Birkás-legelö, 2001. 06. 14 - 07. 19. (tcs., 4)

Platyderus rufus Duftschmid, 1812

Birkás-legelö, 1999. 03. 05 - 03. 31. (tcs., 1): Birkás-legelö, 1999. 04. 01 - 04. 14. (tcs., 1): Birkáslegelö, 1999. 04. 25 - 05. 22. (tcs., 2): Birkás-legelö, 1999. 05. 22 - 06. 24. (tcs., 5): Birkás-legelö, 2001. 05.07 - 06. 14. (tcs., 2): Kolláti-legelö, 2002. 03.14. (egy., 1db.): Birkás-legelö, 2002. 04. 26. (egy., 1 db.): 2002. 06. 16. (tcs., Sz.Cs.,2)

Calathus fuscipes Goeze, 1777

1998. 05. 16 - 06. 22. (tcs., 1): Birkás-legelö, 1999. 04. 25 - 05. 22. (tcs., 1): Kolláti-legelö, 2000. 06. 04.(1 db.): Birkás-legelö, cseres, 2002. 06. 13 07. 15 (tcs.,3): Birkás-legclö, akácos, 2002. 06. 13 07. 15 (tcs.,2): Birkás-legelö, fenyves, 2002. 06. 13 07.15 (tcs.,1)

Calathus erratus C.R. Sahlberg, 1827

1998.04.24.(cgy., 3): 1998. 04. 24 - 05. 15. (tcs.,1): 1998. 04. 24. (egy.,2): 1998. 05. 16 -06. 22. (tcs., 6): Kolláti-legelő, 1999. 04. 01 - 04. 14. (tcs., 1): Kolláti-legelö, 1999. 04. 15 - 05. 22. (tcs., 2): Kolláti-legelö, 1999. 05. 22 - 06. 24. (tcs., 3): Kollátilegelö, 1999. 09. 07. (egy.,1): Birkás-legelö, 1999. 04 .01 - 04. 14. (tcs., 1): 2002. 06. 16. (tcs., Sz.Cs.,9): Birkás-legelö, cseres, 2002. 06. 13 - 07. 15 (tcs.,1): Birkás-legelö, akácos, 2002. 06. 13 - 07.15 (tcs.,2)

Calathus melanocephalus (Linnaeus, 1758)

2002. 06. 16. (tcs., Sz.Cs.,1): Birkás-legelö, aká- cos, 2002. $06.13-07.15$ (tcs., 1)

Synunchus vivalis Illiger, 1798

Birkás-legelő, 2001. 06. 14 - 07. 19. (tcs., 1):

2002. 06. 16. (tcs., Sz.Cs.,7)

Oxypselaphus obscurus (Herbst, 1784)

2002. 06. 16. (tcs., Sz.Cs.,2)

Platynus livens (Gyllenhal, 1810)

2002. 06. 16. (tcs., Sz.Cs.,6)

Platynus assimilis Paykull, 1790

Birkás-legelö, 2001. 05. 07 - 06.1 4. (tcs., 3): 2002. 06. 16. (tcs., Sz.Cs.,35)

Platynus krynickii (Sperk, 1835)

2002. 06. 16. (tcs., Sz.Cs.,7)

Agonum moestumDuftschmid, 1812

láprét L1, 2001. 06. 17 - 07. 09. (tcs., Sz.Cs., 4): 2002. 06. 16. (tcs., Sz.Cs.,35): Kolláti-legelő, 2002. 06. 19. (fcs., 2)

Europhilus thoreyi thoreyi Dejean, 1828

Kolláti-legelö, 2001. 06. 16. (fcs., 1): 2001.07. 11.(fcs., Á.L., 5), Kolláti-legelö, 2002. 06. 19. (fcs., 2) Amara aenea Dee Geer, 1774

Birkás-legelö, 2001. 04. 10 - 04. 18. (tcs., 1): Birkás-legelö, 2001. 04. 18 - 04. 25. (tcs., 1): Birkáslegelö, 2001. 05. 07 - 06. 14. (tcs., 1): Birkás-legelö, 2002. 04. 26. (egy., 2): 2002. 06. 16. (tcs., Sz.Cs., 18): Birkás-legelő, akácos, 2002. 06. 13 - 07.15 (tcs.,7)

Amara communis (Panzer, 1797)

2002. 06. 16. (tcs., Sz.Cs.,2)

Amara convexior Stephens, 1828

Birkás-legelő (5.sz.terület), 2002. 05. 04. (fh.,M.O.,1):

Amara saphyrea Dejean, 1828

1998. 04. 24 - 05. 15. (tcs., 1): Birkás-legelö, 2000. 04. 29. (egy., 1) Birkás-legelö, 2002. 04. 16. (R.I., egy.,1): Birkás-legelö, 2002. 04. 26. (egy., 2): Birkás-legelő (5.sz.terület), 2002. 05. 04. (fh.,M.O.,1):

Amara familiaris (Duftschmid, 1812)

Birkás-legelö, 2002. 04. 26. (fh., P.A., 1)

Amara crenata Dejean, 1828

2001. 07.31. (fcs., Á.L., 3): 2001. 08. 16. (fcs., Á.L., 3)

Amara anthobia A. et G.B. Villa, 1833

Birkás-legelö, 2002. 04. 26. (egy., 2)

Amara gebleri Dejean, 1831

Birkás-legelö, 2001. 06. 14 - 07. 19. (fcs., 1):

2002. 06. 16. (tcs., Sz.Cs.,6)

Zabrus tenebrioides (Goeze, 1777)

1999. 06. 29. (Á.L., 3):

Amblystomus metallescens (Dejean, 1829)

2002. 06. 19. (fcs., 1)

Chlaenius nitidulus Schrank, 1781

1998. 04. 24 - 05. 15. (tcs., 1): Kolláti-legelö, 2000. 04. 11. (egy., 1): 2002. 06. 16. (tcs., Sz.Cs.,1)

Chlaenius vestitus Paykull, 1790

2001.05. 16. (fcs.,Á.L., 1): 2002. 06. 16. (tcs., Sz.Cs.,1)

Chlaenius nigricornis (Fabricius, 1787)

2002 .06. 16. (tcs., Sz.Cs.,2)

Oodes helopioides Fabricius, 1792

láprét L1, 2001. 06. 17 - 07. 09. (tcs., Sz.Cs., 1)

Licinus depressus (Paykull, 1790) 
Birkás-legelô, 2001.05. 07 - 06. 14. (tcs., 1)

Badister bullatus Schrank, 1798

Birkás-legelö, 2001. 06. 14 - 07. 19. (tcs., 1)

Badister lacertosus Sturm, 1815

Birkás-legelő, 2001. 04. 10 - 04. 18. (tcs., 1):

Birkás-legelö, 2001. 05. 07 - 06. 14. (tcs., 3): Birkás-

legelö, 2001. 06. 14 - 07. 19. (tcs., 1)

Badister unipustulatus Bonelli, 1813

Kolláti-legelő, 2001. 06. 16. (fcs., 1): 2001. 07.

31. (fcs., Á.L., 1): 2001. 07. 11. (fcs., Á.L., 1),

Kolláti-legelö, 2002. 06. 19. (fcs., 1)

Badister sodalis (DUFTSCHMID, 1812)

Birkás-legelö, 2002. 04. 26. (egy., 1)

Badister peltatus Panzer, 1797

Kolláti-legelö, 2001. 06. 16. (fcs., 2): 2001. 07.

11. (fcs., Á.L., 2), Kolláti-legelö, 2002. 06. 19. (fcs.,2)

Lebia cruxminor (Linnaeus, 1758)

Kolláti-legelő, 2001. 04. 26. (R.I., 1): Birkás-legelö, 2001. 07. 19.(egy., 1): Kolláti-legelö, 2001. 10.

05. (R.I., 1)

Anisodactylus binotatus (Fabricius, 1787)

2002. 06. 16. (tcs., Sz.Cs.,4)

Stenolophus mixtus Herbst, 1784

Kolláti-legelö, 2001. 06. 16. (fcs., 1): 2001. 07.

11. (fcs., Á.L., 1), Kolláti-legelő, 2002. 06. 19. (fcs.,16)

Stenolophus teutonus Schrank, 1781

Kolláti-legelő, 2002. 06. 19. (fcs.,1)

Stenolophus steveni Krynicki, 1832

2001. 07. 11. (fcs., Á.L., 22)

Anthracus consputus Duftschmid, 1812

2001. 07. 11. (fcs., Á.L., 2):

Acupalpus meridianus (Linnaeus, 1761)

Birkás-legelö, 2002. 05. 04. (ah.,M.O.,1):

Acupalpus maculatus (Schaum, 1860)

2001. 07. 11. (fcs., Á.L., 2): 2002. 06. 16. (tcs.,

Sz.Cs., 1): Kolláti-legelő, 2002. 06. 19. (fcs., 5)

Acupalpus parvulus (Sturm, 1825)

2001. 07. 11. (fcs., Á.L., 2)

Parophonus maculicornis (Duftschmid, 1812)

Kolláti-legelö, 2001. 04. 26. (egy.,R.I.,1):

Ophonus nitidulus Stephens, 1828

1998. 04. 24- 05. 15. (tcs., 1): Birkás-legelő,

200106.14 - 07. 19. (tcs., 2): 2002. 06. 16. (tcs., Sz.Cs.,3)

Ophonus puncticollis Paykull, 1798

2001. 07. 11. (fcs., A.L., 1): 2001. 08. 16. (egy.,

2): 2001.08 .16 (fcs., Á.L., 2)

Pseudophonus griseus Panzer, 1797

2001. 07. 31. (fcs., Á.L., 1): 2001. 08. 16. (fcs, Á.L., 9)

Pseudophonus rufipes De Geer, 1774

2001. 07. 31. (fcs., Á.L., 2): 2001. 07. 11. (fcs., Á.L., 1): Kolláti-legelő, 2001. 10. 05. (egy., 2): 2002. 06. 16. (tcs., Sz.Cs.,4): Birkás-legelő, akácos, 2002 06. 13 - 07. 15. (tcs.,1)

Pseudophonus calceatus Duftschmid, 1812

2001. 08. 16. (fcs., Á.L., 3)

Harpalus atratus Latreille, 1804

Birkás-legelő, 2001. 05. 07 - 06. 14. (tcs., 1)
Harpalus anxius Duftschmid, 1812

2002. 06. 16. (tcs., Sz.Cs., 1)

Harpalus distinguendus Duftschmid, 1812

Kolláti-legelő, 1999. 03. 05 - 03. 31. (tcs., 1)

Harpalus froelichi Sturm, 1818

2001.07.31. (fcs., Á.L., 1): 2001.08. 16. (fcs., Á.L., 2):

Harpalus latus Linnaeus, 1758

Kolláti-legelö, 1999. 04. 15 - 05. 22.( tcs., 2):

Birkás-legelő, 2000. 06. 04. (egy., 1): Birkás-legelö, 2001. 05. 07 - 06. 14. (tcs., 3): égeres, 2001. 06.17. 07. 09. (tcs., Sz.Cs., 1): 2002. 06. 16 .(tcs., Sz.Cs., 1)

Harpalus marginellus Dejean, 1829

Birkás-legelö, 2001. 10. 05. (egy.,1)

Harpalus politus Dejean, 1829

1998. 04. 24 - 05. 15. (tcs., 1): 1998. 05. $16-06$.

22. (tcs., 2): Kolláti-legelő, 1999. 03. 05 - 03. 31.

(tcs., 3): Kolláti-legelő, 1999. 04. 01 - 04. 14. (tcs.,2);

Kolláti-legelö, 1999. 04. 15 - 05. 22. (tcs., 3): Kolláti-

legelö, 1999. 05. 22 - 06. 24. (tcs., 1): 2002. 06. 16.

(tcs., Sz.Cs.,2)

Harpalus pumilus Sturm, 1818

Kolláti-legelö, 2000. 04. 11. (cgy., 7): Kollátilegelő, 2001. 03. 10. (egy., 1): Kolláti-legelő

(1.sz.terület), 2001. 07. 05. (fh.,M.O.,3)

Harpalus serripes serripes Quensel in Schönherr, 1806

1998. 04. 24 - 05. 15. (tcs., 2): 1998. 05. 16 - 06.

22. (tcs., 4): Birkás-legelö, 1999. 04. 25 - 05. 22.

(tcs., 1): Kolláti-legelő (1.sz.terület), 2001. 07. 05.

(fh.,M.O.,1): Birkás-legelö (5.sz.terület), 2002. 05.

04. (fh.,M.O.,1):

Harpalus servus (Duftschmid, 1812)

2002. 06. 16. (tcs., Sz.Cs., 2): Kolláti-legelö

(1.sz.terület), 2001. 07. 05. (fh.,M.O.,1)

Harpalus smaragdinus (Duftschmid, 1812)

1994. 09. 01.(Á.L., 1): 2002. 06. 16.(tcs., Sz.Cs.,1)

Harpalus tardus (Panzer, 1797)

Birkás-legelö, 2001. 05. 07 - 06. 14. (tcs., 1):

Birkás-legelö (5.sz.terület), 2002. 05.04 .

(fh.,M.O.,1): 2002. 06. 16. (tcs., Sz.Cs.,3)

Harpalus subcylindricum Dejean, 1829

2002. 06. 16. (tcs., Sz.Cs., 2)

Demetrias atricapillus (LINNAEUS, 1758)

Birkás-legelö, 2002. 04. 26. (egy., 1)

Syntomus obscuroguttatus (Duftschmid, 1812)

Birkás-legelő, 2002. 05. 04. (ah.,M.O.,1):

Syntomus pallipes (DEJEAN, 1825)

Birkás-legelö, 2001. 10. 05. (cgy.,2)

Microlestes minutulus (GOEZE, 1777.)

Birkás-legelö, 2001. 10. 05. (egy.,2)

Drypta dentata Rossi, 1790

Kolláti-legelő, 1999. 04. 01 - 04. 14. (tcs., 1)

Paradromius linearis (Olivier, 1795)

Birkás-legelö, 2001. 04. 25. (fh., 1)

Calodromius spilotus Illiger, 1798

Birkás-legelö, 2000. 04. 20. (1 db.) 


\section{Értékelés}

A Látrányi Puszta Természetvédelmi Területéről vizsgálatainkban eddig 120 futóbogár faj került elő. Ha figyelembe vesszük a terület kis méretét (alig több mint 200 ha), ezt elég magas számnak tekinthetjük. Az eddigi vizsgálatok elsősorban arra irányultak, hogy általános képet kapjunk a terület futóbogár közösségeiröl, ezért túlnyomó szerepet kapott a talajcsapdázás, mint mintavételi módszer. A futóbogarak csak egy része gyüjthető jól talajcsapdázással, ezért úgy vélem, más módszerekkel, elsősorban fénycsapdázással tovább növelhető a területről kimutatott fajok száma.

A fajösszetételt megvizsgálva meglepő eredményeket nem kapunk. A futóbogarak nagyobb része nedvességkedvelö, a csapdázások is a vizes élöhelyeken volt intenzívebb, így nem meglepő, hogy a begyüjtött fajok többsége ebböl a csoportból került elő. Néhány országosan ritka faj jelenlétét is sikerült kimutatni, mint például a Leistus piceus$\mathrm{t}$, a Harpalus latus-t, azonban az is igaz, hogy Somogy megye hasonló élöhelyein rendszeresen, néha nagy számban találhatóak ezek. Ez természetesen nem von le a vizsgált terület értékéböl, inkább kiemeli a Dél- Dunántúli természetes állapotú vizes élőhelyek megőrzésének fontosságát.

Összességében megállapithatjuk, hogy a területen található láprétek, az árkok menti galéria erdők és égerligetek futóbogár faunája mind a fajszám, mid az egyedszámok tekintetében gazdag és a tájegységre nagyon jellemző.

A száraz pusztagyepek faunájának felmérése sokkal nehézkesebb és érzésem szerint ezen a területen még sok újdonság kerülhet elö. Az élöhely kis eltartó képessége miatt az itt élö fajok viszonylag alacsony egyedszámban fordulnak elö, ezért a talajcsapdás mintavételezés nem hozott kielégítő eredményt. Az innen elökerült fajok túlnyomó többsége a 3-4 fénycsapdás gyüjtésből ered, köztük ritka fajok is.

Vizsgálatainkban kilenc olyan faj került elö, melyet Somogy megyében eddig még nem mutattak ki, ezek: Bembidion mannerheimi, Porotachis bisulcatus, Harpalus latus, Harpalus subcylindricum, Amara crenata, Stenolophus steveni, Calodromius spilotus, Amblystomus metallescens, Acupalpus meridianus.

Összesen 8 védett futóbogár faj került elö (ami szintén magas fajszámnak tekinthető), 7 Carabus faj és a Cychrus caraboides, némelyik igen nagy egyedszámban.

\section{Természetvédelmi vonatkozások}

A Látrányi pusztán végzett vizsgálatok egyértelmüen igazolták az előzetes várakozásokat. A változatos és többnyire természet közeli állapotban fennmaradt élőhelyek futóbogár faunája gazdag, mind a fajszámot, mind a fajösszetételt tekintve. A fauna megörzésének elsődleges feltétele, hogy az értékes élőhelyek jó állapotát megörizzük és lehetőség szerint a leromlókat feljavítsuk.

A terület kicsinysége és kedvezőtlen tulajdonszerkezete, a müvelés hiánya miatt, az élöhelyek megörzése csak aktív beavatkozással, kezeléssel, néhány területen pedig élöhely rekonstrukcióval oldható meg.

Szükségessé vált és nem halogatható a gyomosodó rétek rendszeres kaszálása, mert a Solidago rohamosan terjed. Ehhez kapcsolódóan szükséges a korábban leszárított láprétek vízellátásának megoldása, így a két beavatkozás sikeres rekonstrukciót jelentene a kezelésbe vont területeken.

Az utóbbi években folyamatosan nött a területen illegálisan lerakott szemét mennyisége és elérte azt a szintet, hogy komolyan veszélyezteti néhány nagyon értékes élőhely fennmaradását. 
Fontos feladat a nyílt homokpuszta gyepek fenntartása. Állapotuk az utóbbi években stabilnak tekinthető, azonban csapadékos években a gyep záródása figyelhető meg, ami néhány értékes faj eltünését eredményezheti. Megoldást jelenthet a szükség szerinti legeltetés.

\section{Köszönetnyilvánítás}

Köszönetemet fejezem ki a programban résztvevő kutatóknak, Ábrahám Leventének, Merkl Ottónak, Podlussány Attilának, Rozner Istvánnak, Szinetár Csabának az általuk gyüjtött anyag rendelkezésemre bocsátásáért. Köszönet illeti Lökkös Andort, aki a terepi munkában is segítségemre volt.

Külön szeretnék köszönetet mondani Szél Győzőnek a problémás fajok határozásában nyújtott segítségéért.

\section{Irodalom}

CSIKı E. 1904-08: Magyarország bogárfaunája 1. kötet Adephaga 1 Caraboidea. Budapest pp.1-455.

HoRvatovich S. 1974.: Futóbogarak II. Carabidae II.- Faun. Hung. 4: 1-40.

HoRVATOVich S. 2001.: Somogy megye futóbogarainak (Coleoptera: Carabidae) katalógusa - Natura Somogyiensis $1 .: 135-143$.

HURKA K. 1996.: Carabidac of the Czech and Slovak Republics. Kabourek Zlin. pp. 1-565.

\section{Investigation on Carabid fauna of the Látrányi Puszta Nature Conservation Area (Coleoptera: Carabidae)}

\section{GYÖRGY ROZNER}

The studied area has been a protected area since 1992, where, in an extremely mosaic arrangement, a rather diverse surface can be found: sandy grasslands developed on the calciferous sand, different types of marshlands and marshy meadows, just as well as small various forest associations. The research work focused partly on the surveying of the present condition of the area, and partly on estimating the necessary treatment demanded by the future.

During the course of our research, the occurrence of nine species, all new to the region of Somogy County, was recorded, such as: Bembidion mannerheimi, Porotachis bisulcatus, Harpalus latus, Harpalus subcylindricum, Amara crenata, Stenolophus steveni, Calodromius spilotus, Amblystomus metallescens, Acupalpus meridianus.

Altogether there were 8 protected Carabid species found (that can be considered a fairly high number as well), 7 Carabus species and Cychrus caraboides. Some of them occurred in great number. 